\title{
Determinants Taxpayer Compliance: The Role Of Fine, Procedural Justice And Trust Authorities Tax
}

\author{
Ni Putu Riasning, Anak Agung Bagus Amlayasa, Luh Kade Datrini \\ $\{$ info@warmadewa.ac.id $\}$
}

Universitas Warmadewa, Denpasar, Bali

\begin{abstract}
This study examined the role of penalties, procedural justice and trust tax authorities in improving tax compliance. It focused on individuals in Denpasar and Badung to analyze the level of tax compliance. A total of 98 taxpayers in the city of Denpasar and Badung were selected as samples. The data were processed and analyzed and hypothesis tested using SmartPLS 3.0. The results showed that fines negatively affects tax authorities. Also, interaction with keadian procedural penalties has no significant positive effect on taxpayers confidence of tax authorities and compliance.
\end{abstract}

Keywords: Fines, Procedural Fairness, Trust Tax Authorities, Taxpayers Compliance

\section{Introduction}

The state revenue from the tax sector is the main pillar of income in the state budget is used to meet the needs of government spending in the context of national development. Nevertheless, the tax revenue is low indicated by a lower tax ratio Indonesia when compared with countries in Southeast Asia. The higher the tax rate of a country, the higher the tax compliance in paying taxes. Tax ratio in Indonesia reaches $11-12 \%$ of GDP. This is relatively low compared to the ideal tax rate, which is about $15-17 \%$. Indonesia has a tax rate lower than neighboring countries such as the Philippines (12, 9\%), Singapore (14\%), Thailand (16, 5\%), and Malaysia (16, 1\%) [1]. The low tax ratio Indonesia is very worrying for the needs of government spending actually increased especially with the threat of a global crisis. Therefore, the Directorate General of Taxes need to optimize the policy of increasing tax revenue. Tax revenues are the backbone (backbone) Indonesia budget forced the government to develop the innovation policy of increasing tax revenue. The policy innovation by increasing the capacity of the Directorate General (DG) of Taxation, tax officials add and strengthen the tax infrastructure, Tax Directorate, as the competent authority, further increasing the massive checks to taxpayers who allegedly violated tax laws (tax evaders) and increasing tax penalties. However, this policy is contrary to the literature and the results of studies showing that the economic variables 
detterence (inspection and tax penalties) only increase tax compliance forced (enforced tax compliance). In the long term, the policy of using checks and tax penalties will be less effective because of the high tax ratio can only be achieved if there has been a voluntary tax compliance [2], [3] [1] states that a low tax rate can not be considered the fault of the Directorate General of Taxation, for matters concerning the tax is the duty of every citizen to develop this country. Therefore, the tax authorities should also consider the social psychology variables that tend to improve voluntary tax compliance (voluntary tax compliance).

Results of previous studies show that the personal tax compliance in Indonesia still be enforced tax compliance with tax penalties become the main determinant [4]. However, as described above, the policy of increasing tax penalties are less effective in improving voluntary tax compliance [2], [3]. Therefore, this study developed a model of voluntary tax compliance by combining the tax penalty with social-psychological variables such as procedural fairness and confidence in the tax authorities. Indonesia is still low tax ratio can be a serious problem because the government has insufficient funds to shopping development activities in the coming period. This problem is exacerbated by rampant corruption cases taxes actually much do tax authorities themselves that could lead to people unwilling to pay taxes. The government has tried to make innovation policy but has not supported empirically study whether the policy effectively improve voluntary tax compliance.

Research on the model of tax compliance with the perspective of social psychology interesting to study because it is motivated by that tax compliance is an important factor for the increase in state revenue taxes. To reach the target, as mandated in the state budget, increasing the number of taxpayers need to be grown continuously awareness and compliance of taxpayers to pay tax in accordance with applicable regulations. Next the researchers focused research tax compliance behavior by developing a social psychological theory.

\section{Methodology}

\subsection{Slippery Slope Theory Model}

One of the current theories about the slippery slope of tax compliance is a model of [3], This theory states that social and psychological variables detterence positive effect on tax compliance. Variable social-psychological tend to affect tax compliance is voluntary (voluntary tax compliance) while variable deterrence is likely to affect tax compliance based on the fear of negative consequences (tax compliance imposed / enforced. Policies to improve tax compliance is voluntary depending on the level of public confidence in the tax authorities (trust in authorities). Policies such as checks and tax penalties are likely to increase the perception of the strength of the tax authority (power of authorities) that would affect tax compliance enforced. Based on the slippery slope theory is the policy of increasing public confidence in the tax authorities should be prioritized in order to improve voluntary tax compliance (tax compliance). Policies to improve voluntary tax compliance depends on the level of public confidence in the tax authorities (trust in authorities). Policies such as checks and tax penalties are likely to increase the perception of the strength of the tax authority (power of authorities) that would 
affect tax compliance enforced. Based on the slippery slope theory is the policy of increasing public confidence in the tax authorities should be prioritized in order to improve voluntary tax compliance Policies to improve voluntary tax compliance depends on the level of public confidence in the tax authorities (trust in authorities). Policies such as checks and tax penalties are likely to increase the perception of the strength of the tax authority (power of authorities) that would affect tax compliance enforced. Based on the slippery slope theory is the policy of increasing public confidence in the tax authorities should be prioritized in order to improve voluntary tax compliance Policies to improve voluntary tax compliance depends on the level of public confidence in the tax authorities (trust in authorities). Policies such as checks and tax penalties are likely to increase the perception of the strength of the tax authority (power of authorities) that would affect tax compliance enforced. Based on the slippery slope theory is the policy of increasing public confidence in the tax authorities should be prioritized in order to improve voluntary tax compliance,

\subsection{Tax Penalties}

One method of government in improving revenue from the tax is to give formal sanction in the form of tax penalties to punish non-compliance. Nevertheless, the results of research show empirical evidence to the contrary about the effect of sanctions against the level of compliance. There are several studies which showed that giving sanctions can improve compliance [5]-[7], however there are other studies that show pemberikan actually reduce tax penalties obedience (Mulder, van Dijk, De Cremer, \& Wilke, 2006; Van Prooijen, Gallucci, \& Toeset 2008). There are two perspekti in behavioral literature why penalty tax may affect compliance. Instrumental perspective states that sometimes advantageous to not abide by the rules if the sanction for the offense smaller than the gains from the violation. Therefore, the instrumental perspective emphasizes that the level of sanctions should outweigh the benefits of doing such abuses second perspective is called relational perspective which states that any deterrence variables (such as fines and tax inspection) is not enough to explain the system of sanctions. Perspective is based on concepts such as procedural justice (procedural fairness), confidence (trust), and the moral evaluation of the tax authorities to explain why a tax penalty may improve compliance. One hypothesis is important from this perspective is the level of sanctions (fines tax) higher can improve compliance only if sanctioned by the authority granting procedure is deemed reasonable and fair (fair).

\subsection{Procedural Justice}

The public perception of the justice system of taxation applicable in a greatly affect the implementation of good tax in the country. The public perception of this will affect the behavior of tax compliance and tax avoidance behavior (tax evasion). People will tend not compliant and avoid tax liability if they feel the tax system that is unfair. In other words, procedural justice moderates the relationship between the level of tax penalties and tax compliance. Some research indicates that procedural justice has positive influence on tax compliance (Berutu \& Harto, 2013; Wulandari \& Budiaji, 2018)

\subsection{Trust Authority Taxpayers}


Trust authorities taxpayer in this research is the belief in the legal system and the administration. The level of confidence in the legal system and government is a belief that underlies every community in this regard the taxpayer to the legal system and government are in Indonesia and its relation to the implementation of the tax system in Indonesia is giving to that expected by society or even not in line with expectations Public (Fitriana, 2012).Wajib taxes are satisfied with the services provided are likely to carry out tax obligations in accordance with the rules and regulations (Anggraeni \& et al, 2013), Murphy, (2004) showed that confidence in the tax authorities also mediates the influence of procedural justice on tax compliance. Kirchler et al., (2008) stated that the confidence (trust) to the tax authorities is an important determinant variable for voluntary tax compliance.This study uses quantitative methods to deploy 98 questionnaire to taxpayers in Denpasar and Badung. All data can be processed and analyzed. Measurement of study variables using questionnaire that has been used by previous studies and has been tested for validity and reliability. Variable levels of voluntary tax compliance is measured with an instrument of Wenzel, (2004) with 3 questions on a scale of 5 points. Variable tax penalty is measured by the instrument ofVerboon \& van Dijke, (2011) with 2 questions on a scale of 5 points .. Variables procedural fairness is measured with an instrument of [16], [17]4 items with questions on a scale of 5 points. Variables measured confidence in the tax authorities of the instrumentMulder, Verboon, \& De Cremer, (2009) with item 3 questions on a 5 point scale. The data is processed and analyzed with the help SmartPLS 3.0 used to test the hypothesis.

\section{Results And Discussion}

\subsection{Description of the Research Object}

Data was collected by spreading questionnaire distributed directly to the taxpayer in Denpasar and Badung. A total of 100 questionnaires were distributed. Of that number, 98 respondents answered in full so that there is a proper 98 can be processed further.

\subsection{Model Evaluation Measurement}

In connection with the indicators that make up the latent variables in this study is reflexive, then the evaluation of the measurement model (measurement model / outer model), to measure the validity and reliability of the indicators obtained results concerning the value of outer loading showing all the indicators are qualified valid by kriteia discriminant validity outer loading a value $>0,70$ and significant statitstik:

Table1. Outer Loading Estimation Model

\begin{tabular}{ccc}
\hline Indicator & & Loading Outer Value \\
\hline Denda1 & 0,981 & \\
Denda2 & 0.980 & \\
Kep1 & & 0,972 \\
\hline
\end{tabular}




\begin{tabular}{llll}
\hline Kep2 & 0.952 & & \\
Kep3 & 0.949 & & \\
Pros1 & & 0.932 & \\
Pros2 & & 0.912 & \\
Pros3 & & 0.944 & \\
Pros4 & 0.766 & \\
Trust1 & & 0.925 \\
Trust2 & & 0.938 \\
Trust3 & & & 0.881 \\
\hline
\end{tabular}

\subsection{Discriminant Validity}

A variable is said to be valid, if the root of AVE ( $\mathrm{A}$ VE or Square root Average Variance Extracted) each construct is greater than the value of the correlation between constructs (Ramayah, Cheah, Chuah, Ting, and Memon, 2018) and each value AVE is greater than 0.50.

Table 2. Test Discriminant Validity

\begin{tabular}{lcc}
\hline Construct & & \\
& AVE & VAVE \\
& & \\
\hline Fines (X1) & 0,981 & 0,990 \\
Compliance (Y) & 0.958 & 0.979 \\
Procedural (Mod) & 0.891 & 0.944 \\
Trust (Med) & 0.915 & 0.957 \\
\hline
\end{tabular}

\subsection{Composite Reliability and Cronbach Alpha}

A measure can be said to be reliable, if the composite reliability and Cronbach alpha has a value greater than 0.70 . Composite reliability and Cronbach's alpha is a measure of reliability between blocks of indicators in the research model.

Table 3.Composite Test Reliability and Cronbach Alpha 


\begin{tabular}{lcc}
\hline & Cronbach's & composite \\
& Alpha & Reliability \\
\hline Fines (X1) & 0,961 & 0,981 \\
Compliance (Y) & 0,955 & 0,971 \\
Procedural (Mod) & 0,911 & 0,939 \\
Trust (Med) & 0,903 & 0,939 \\
\hline
\end{tabular}

\subsection{Evaluation of Structural Model}

Evaluation of the structural model (Structural Model / Inner Model) is a measurement to evaluate the accuracy of the model in the study as a whole, formed by several variables along with their indicators. In the evaluation of the structural model will be carried out using the RSquare (R2). (R2) indicates the strength of the effect caused by the dependent variable to the independent variables. R-Square (R2) can also indicate the strength of a research model as to know that the value of $\mathrm{R}$ square Variable Trus (Y1) is 0,579 , which means that $57.9 \%$ of the variation can be explained by the interaction trust tax penalty with keaadilan procedural and the remaining $42,1 \%$ is influenced by other variables outside the model and $\mathrm{R}$ Square variable compliance (Y2) is 0.602 value tax compliance unexplained variation Trust(Y1) of $60.2 \%$ by interaction keaadilan tax penalty with the procedural and the remaining $39.8 \%$ influenced by other variables diuar models.

\subsection{Path Analysis and Testing Hypotheses}

Testing the hypothesis, which is expected is Ho refused or sig $<0.05$ (or the value of the $t$ statistic $>1.96$ with a significant level of 0.05 ).

Table 4. Results of Hypothesis Testing

\begin{tabular}{lcc}
\hline \multicolumn{1}{c}{ Construct } & $\begin{array}{c}\text { Original Sample } \\
\text { P Values }\end{array}$ & $(\mathrm{O})$ \\
\hline Fines (X1) -> Trus (Y1) & -0.228 & 0,438 \\
Fines * Procedural (moderating effect) & 0579 & 0596 \\
Procedural (M) -> Compliance (Y2) & 0685 & 0000 \\
Procedural (M) -> Trust (Y1) & 0982 & 0000 \\
Trust (Y1) -> Compliance (Y2) & 0119 & 0416
\end{tabular}

Based on the results in Table 4, the construction of the model can be presented the following results: 


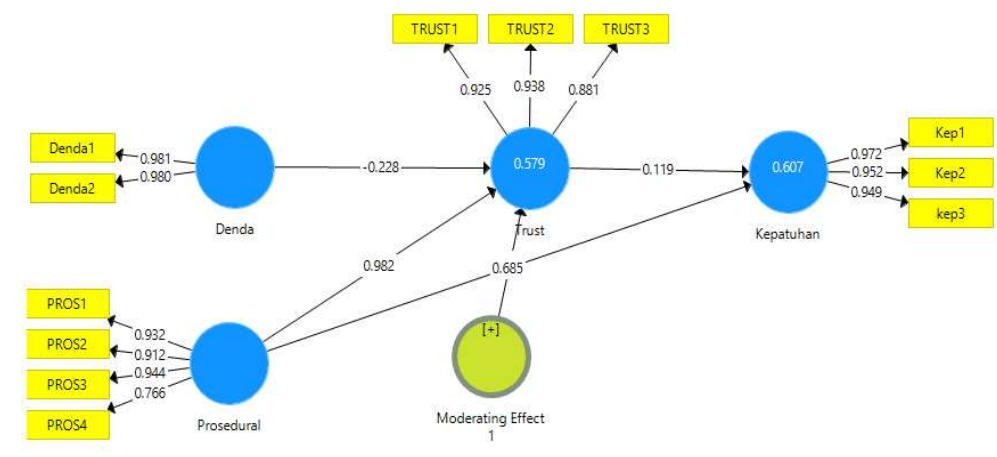

\section{Conclusion}

Based on data analysis in this study can be summarized as follows 1) Fines negative effect on the trust authority (Trust) and the relationship is not significant at the 0.05 level. Hypothesis 1 was not supported. This can be explained that the decrease of the tax penalty that drefleksikan by the growing severity of penalties but not necessarily able to boost Trus indicated by a high respect for the honesty of tax authorities, 2) Interaction with keadian procedural penalties as securities moderation positive effect on trust authority (Trust) and the relationship is not significant at the 0.05 level. Hypothesis 2 was not supported. This can be explained that increasing fines interaction with procedural justice, but not necessarily able to increase the Trust indicated by a high respect for the honesty of tax authorities, 3) Trust authority (Trus) positive effect on tax compliance and the relationship is not significant at the 0.05 level. Hypothesis 3 was not supported. This can be explained that increasing the Trust indicated by a high respect for the honesty of tax authorities but not necessarily able to increase taxpayer compliance which is reflected by the taxpayer to report lower than actual income to the tax office.

\section{References}

[1] A. Nurwanah, T. Sutrisno, R. Rosidi, and R. Roekhudin, "Determinants of tax compliance: Theory of planned behavior and stakeholder theory perspective," Probl. Perspect. Manag., vol. 16 , no. 4 , pp. $395-407,2018$.

[2] C. Kogler, L. Batrancea, A. Nichita, J. Pantya, A. Belianin, and E. Kirchler, "Trust and power as determinants of tax compliance: Testing the assumptions of the slippery slope framework in Austria, Hungary, Romania and Russia,” J. Econ. Psychol., 2013.

[3] E. Kirchler, E. Hoelzl, and I. Wahl, "Enforced versus voluntary tax compliance: The 'slippery slope' framework," J. Econ. Psychol., 2008.

[4] N. Cahyonowati, "Model Moral Dan Kepatuhan Perpajakan:," J. Akunt. DAN Audit. Indones., vol. 15 , no. 2, pp. 161-177, 2011.

[5] D. Pujiwidodo, "Persepsi Sanksi Perpajakan Terhadap Kepatuhan Wajib Pajak Orang Pribadi 
Undang-Undang juga dengan pandangan, gambaran atau," J. ONLINE Insa. AKUNTAN, vol. 1, no. 1, pp. 92-116, 2016.

[6] E. Siamena, H. Sabijono, and J. D. . Warongan, "Pengaruh Sanksi Perpajakan Dan Kesadaran Wajib Pajak Terhadap Kepatuhan Wajib Pajak Orang Pribadi Di Manado," Going Concern J. Ris. Akunt., vol. 12, no. 2, pp. 917-927, 2017.

[7] F. S. Elva Nuraina, "Pengaruh sanksi perpajakan terhadap kepatuhan wajib pajak orang pribadi di Kantor Pelayanan Pajak Pratama Madiun," Equilib. J. Ilm. Ekon. dan Pembelajarannya, vol. 5, no. 1, p. 45, 2017.

[8] L. B. Mulder, E. van Dijk, D. De Cremer, and H. A. M. Wilke, "Undermining trust and cooperation: The paradox of sanctioning systems in social dilemmas," J. Exp. Soc. Psychol., 2006.

[9] J. W. Van Prooijen, M. Gallucci, and G. Toeset, "Procedural justice in punishment systems: Inconsistent punishment procedures have detrimental effects on cooperation," Br. J. Soc. Psychol., 2008.

[10] D. A. Berutu and P. Harto, "Persepsi Keadilan Pajak Terhadap Perilaku Kepatuhan Wajib Pajak Orang Pribadi (Wpop)," Diponegoro J. Account., vol. 2, no. 2003, pp. 265-274, 2013.

[11] S. WULANDARI and A. BUDIAJI, "Pengaruh Persepsi Keadilan Pajak Dalam Peraturan Pemerintah Republik Indonesia Nomor 46 Tahun 2013 Terhadap Kepatuhan Dalam Memenuhi Kewajiban Perpajakan,” Islam. J. Ekon. Islam, vol. 8, no. 2, pp. 239-268, 2018.

[12] S. Fitriana, "PENGARUH PEMAHAMAN TENTANG PERATURAN PERPAJAKAN, PERSEPSI EFEKTIFITAS SISTEM PERPAJAKAN DAN TINGKAT KEPERCAYAAN SISTEM PEMERINTAHAN DAN HUKUM TERHADAP KEMAUAN MEMBAYAR PAJAK WAJIB PAJAK ORANG PRIBADI YANG MELAKUKAN PEKERJAAN BEBAS,” J. Online Mhs., pp. 1-15.

[13] I. Y. Anggraeni and Dkk, "Faktor-Faktor yang Mempengaruhi Kepatuhan Wajib Pajak terhadap Penerimaan Pajak Penghasilan pada Kantor Pelayanan Pajak Pratama Semarang Tengah Satu," Diponegoro J. Soc. Polit., 2013.

[14] K. Murphy, "The role of trust in nurturing compliance: A study of accused tax avoiders," Law and Human Behavior. 2004.

[15] M. Wenzel, "The social side of sanctions: Personal and social norms as moderators of deterrence," Law Hum. Behav., 2004.

[16] P. Verboon and M. van Dijke, "When do severe sanctions enhance compliance? The role of procedural fairness," J. Econ. Psychol., 2011.

[17] T. R. Tyler, "The psychology of legitimacy: A relational perspective on voluntary deference to authorities," Personal. Soc. Psychol. Rev., 1997.

[18] L. B. Mulder, P. Verboon, and D. De Cremer, "Sanctions and moral judgments: The moderating effect of sanction severity and trust in authorities," Eur. J. Soc. Psychol., 2009.

[19] T. Ramayah, J. Cheah, F. Chuah, H. Ting, and M. A. Memon, Partial Least Squares Structural Equation Modeling (PLS-SEM) using SmartPLS 3.0: An updated and practical guide to statistical analysis. 2018. 
